\title{
Effect of GTP on the Affinity of Denopamine, a New Cardiotonic Agent, for $\beta$-Adrenergic Receptors of Turkey Erythrocytes and Rat Reticulocyte Membranes
}

\author{
Kazuaki NAITO, Taku NAGAO, Yasutoshi ONO, Minezo OTSUKA, \\ Shoichi HARIGAYA and Hiromichi NAKAJIMA \\ Biological Research Laboratory, Tanabe Seiyaku Co., Ltd., Toda, Saitama 335, Japan
}

Accepted September 2, 1985

\begin{abstract}
Affinities of denopamine, a new cardiotonic agent, and several $\beta$ adrenergic drugs for turkey erythrocyte membranes (TEM) and rat reticulocyte membranes (RRM) which contain homogeneous $\beta_{1}$ - and $\beta_{2}$-receptors, respectively, were studied by receptor binding. The order of potencies of denopamine and several $\beta$-adrenergic agonists in displacing ${ }^{3} \mathrm{H}$-dihydroalprenolol binding $\left(K_{i}, n M\right)$ in TEM was isoproterenol (Iso, 27)>norepinephrine (Nor, 360)>epinephrine (Epi, 860) $>$ dobutamine (DB, 1380)>denopamine (1540)>dopamine (DA, 49500). The order in RRM was Iso (7.3)>Epi (58)>DB (750)>Nor (1090)>denopamine (2300) $>$ DA (26800). In the presence of GTP. competition curves for full agonists like Iso, Epi and Nor shifted to the low affinity side ( $K_{i}$ values increased by $300-500 \%$ in TEM and $200-460 \%$ in RRM), and the slopes were steepened in both membrane preparations. The $K_{i}$ value for denopamine increased only in TEM (70\%) and that in RRM was not influenced by GTP. This suggests that denopamine has an agonist property at the $\beta_{1}$-receptor but not at the $\beta_{2}$-receptor and that the intrinsic activity at the $\beta_{1}$-receptor of the drug is lower than full agonists. Affinities of DB and DA for TEM were influenced by GTP as well as those for RRM, although the extent of the rightward shift was less than full agonists.
\end{abstract}

Denopamine, $(-)-(R)-1-(p-h y d r o x y p h e n-$ yl) -2-[(3,4-dimethoxy-phenethyl)amino] ethanol, is a new, orally active, positive inotropic agent with a weak chronotropic action (1-3). In the previous paper, we reported that denopamine exhibited a $\beta_{1}$ selective affinity and agonist property (4) by radioligand binding $(5-7)$, using rat heart membranes and lung membranes. In the above report, we demonstrated that the degree of the rightward shift of the competition curve for denopamine by the addition of GTP was less than those for full agonists like isoproterenol, epinephrine and norepinephrine. Since it has been recognized that the degrees of the GTP-induced rightward shift well correspond to the intrinsic activities of $\beta$-agonists $(8,9)$, the agonist property of denopamine was considered to be weak as compared with full agonists. However, the effect of GTP on the affinities for $\beta$-receptors in the previous experiment may be obscured by the coexistence of $\beta_{1}$ and $\beta_{2}$-receptor subtypes in both membrane preparations. The present experiment was carried out to further investigate the agonist property of this drug to the $\beta_{1}$ - and $\beta_{2}$ receptors using turkey erythrocyte membranes and rat reticulocyte membranes which were reported to contain homogeneous $\beta_{1}$ - and $\beta_{2}$-receptors, respectively (10-13). In addition, we compared the degrees of the rightward shift by GTP among several $\beta$ adrenergic agonists in these membrane preparations.

\section{Materials and Methods}

1. Preparation of turkey erythrocyte membranes and rat reticulocyte membranes: The turkey erythrocyte membranes (TEM) and rat reticulocyte membranes (RRM) were prepared by the method of Charness et al. 
(14) with some modifications. Blood was sampled from the axillary vein of male turkeys (about 12 months of age). Reticulocyte-rich blood was obtained from the abdominal aorta of male Sprague-Dawley rats (6-7 weeks of age) injected intraperitoneally with a solution of phenylhydrazine hydrochloride (adjusted to $\mathrm{pH} 7.0$ with saturated aqueous solution of $\mathrm{NaHCO}_{3}$ ) in a dose of $50 \mathrm{mg} / \mathrm{kg} /$ day for 3 days. Rats were sacrificed on the 7th day after the first administration of phenylhydrazine hydrochloride.

One $\mathrm{ml}$ of $0.2 \mathrm{M}$ sodium EDTA was added to the blood sample $(10 \mathrm{ml})$ as an anticoagulant. After blood was centrifuged at $2000 \times \mathrm{g}$ for $5 \mathrm{~min}$, the plasma and buffy coat were removed by aspiration. The cells were two times washed with two volumes of cold $150 \mathrm{mM} \mathrm{NaCl}, 5 \mathrm{mM}$ Tris- $\mathrm{HCl}$ buffer ( $\mathrm{pH} 7.5$ ), followed by centrifugation. Using a syringe with polyethylene tubing, $3 \mathrm{ml}$ (in the case of TEM) or $1 \mathrm{ml}$ (RRM) of packed cells were sampled from the bottom of the tube and lysed in 40 volumes of $5 \mathrm{mM}$ Tris- $\mathrm{HCl}$ buffer $(\mathrm{pH} \mathrm{7.5)}$ for $20 \mathrm{~min}$ with stirring. After the addition of $3 \mathrm{ml}$ (TEM) or $1 \mathrm{ml}$ (RRM) of the mixtures of $4 \mathrm{M} \mathrm{KCl}$ and $40 \mathrm{mM} \mathrm{MgCl}$, the lysate was centrifuged at $28000 \times \mathrm{g}$ for 10 min. The pellet was resuspended, above lysis step was repeated, and the membrane pellet was finally suspended in $100 \mathrm{ml}$ of $50 \mathrm{mM}$ Tris- $\mathrm{HCl}$ buffer $\left(\mathrm{pH} 7.5,25^{\circ} \mathrm{C}\right)$. Erythrocyte membranes from nontreated rats were prepared in the same way as RRM. In all the experiments, the final protein concentrations of TEM. RRM and erythrocyte membranes were about 300,50 and $50 \mu \mathrm{g} / \mathrm{ml}$, respectively. In TEM, $10 \mathrm{mM} \mathrm{MgCl}_{2}$ and $1 \mathrm{mM}$ EDTA were added to the membrane suspension. The above operations were conducted at $2{ }^{\circ} \mathrm{C}$, and all experiments were carried-out on the day of preparation.

2. ${ }^{3} \mathrm{H}$-Dihydroalprenolol (DHA) binding assays: The ${ }^{3} \mathrm{H}$-DHA binding experiment was carried out by the same method reported previously (4). For the binding saturation curves, an aliquot $(1 \mathrm{ml})$ of the rat erythrocyte or reticulocyte membrane suspension was incubated for $30 \mathrm{~min}$ at $25^{\circ} \mathrm{C}$ with various concentrations of ${ }^{3} \mathrm{H}$-DHA (about $0.1-5 \mathrm{nM}$ ) in a total volume of $1.1 \mathrm{ml}$. In the case of TEM, incubation was conducted at $37^{\circ} \mathrm{C}$.
Reaction was stopped by the addition of $8 \mathrm{ml}$ of the ice-cold $50 \mathrm{mM}$ Tris-HCl buffer. The incubated mixture was rapidly filtered through glass fiber filters (Whatman, GF/C) under a vacuum. Each filter was washed with an additional $8 \mathrm{ml}$ of ice-cold buffer. Membranebound radioactivity on the filter was determined in a toluene-Triton $X-100$ scintillation cocktail (12 g DPO, $300 \mathrm{mg}$ POPOP, 2 I toluene, 1 I Triton X-100, $300 \mathrm{ml}$ methanol) using a liquid scintillation spectrometer (Packard, $460 \mathrm{CD}$ ). Specific binding of ${ }^{3} \mathrm{H}$ DHA was defined as the amount of ${ }^{3} \mathrm{H}-\mathrm{DHA}$ bound in the absence of a competing drug minus the amount bound in the presence of $10 \mu \mathrm{M}( \pm)$-propranolol. Specific binding of ${ }^{3} \mathrm{H}-\mathrm{DHA}$ to TEM and RRM was $70-98 \%$ of the total ${ }^{3} \mathrm{H}$-DHA binding, respectively.

In the binding inhibition studies, an aliquot $(1 \mathrm{ml})$ of the membrane suspension was incubated with ${ }^{3} \mathrm{H}$-DHA (about $0.78 \mathrm{nM}$ in TEM and $0.2 \mathrm{nM}$ in RRM) and various concentrations of competing drugs. Specific binding was obtained as described above. Ascorbic acid $(0.1 \mathrm{mM})$ and pargyline $(1 \mu \mathrm{M})$ were included in the incubation mixture to prevent oxidation of catecholamines. If necessary, a small amount of $\mathrm{HCl}(0.15 \mathrm{mM})$ was also added to facilitate solubilization of the test drugs. These chemicals were shown to have no effect on specific ${ }^{3} \mathrm{H}$-DHA binding at the concentration used.

3. Determination of protein concentration: Protein concentration in the membrane fractions of rat erythrocytes and reticulocytes and turkey erythrocytes was determined by the method of Lowry et al. (15) using bovine serum albumin as a standard.

4. Analysis of data: The IC50 of radioligand competition curve was determined by the $X$-intercept of linearized plots of $\log [B /$ $\left.B_{m a x}-B\right]$ vs. $\log . C$. where $B$ is the amount of ${ }^{3} \mathrm{H}$-DHA bound in the presence of competing drugs, $B_{\max }$ is the amount of the radioligand bound in the absence of competing drugs and $\mathrm{C}$ is the concentration of competing drugs. The slope ( $b$, Hill coefficient) of the competition curve was derived from a logistic curve of 4 parmeters described below (16):

$$
Y=\frac{a-d}{1+(\bar{X} / c)^{-b}}+d
$$


where $Y$ is a specific binding at the test drug concentration of $X$. Symbols of $c$, a and $d$ are IC50, maximum (100\%) and minimum (0\%) value of the ${ }^{3} \mathrm{H}-\mathrm{DHA}$ binding, respectively. Values of the inhibition constant $\left(K_{i}\right)$ for the competing drugs were calculated from the IC50 by the following equation (17):

$$
K_{i}=1 C 50 /\left(1+L / K_{d}\right) \text {. }
$$

where $L$ is the concentration of the radioligand in the incubation mixture, and $K_{d}$ is the equilibrium dissociation constant of ${ }^{3} \mathrm{H}$ DHA for the binding site. Student's $t$-test was employed to assess the statistical significance.

5. Materials: ${ }^{3} \mathrm{H}$-Dihydroalprenolol (DHA. specific activity: $77 \mathrm{Ci} / \mathrm{mmol}$ ) was obtained from Amersham. (-)-Isoproterenol Dbitartrate, (-)-norepinephrine, (-)-dopamine hydrochloride and $( \pm)$-propranolol hydrochloride were obtained from Nakarai Chemicals (Japan), and (-)-epinephrine was purchased from Merck. Denopamine and practolol were synthesized at the Organic Chemistry Research Laboratory. Tanabe Seiyaku Co., Ltd. (Toda, Saitama, Japan). Dobutamine hydrochloride, prenalterol hydrochloride and procaterol were extracted from the commercially available drugs. Other drugs and chemicals used in the experiment were as follows: guanosine $5^{\prime}$-triphosphate $3-\mathrm{Na}$ (GTP, Yamasa Shoyu Co., Ltd., Japan), /ascorbic acid, pargyline hydrochloride. phenylhydrazine hydrochloride. EDTA 2- $\mathrm{Na}$ and bovine serum albumin (Nakarai Chemicals).

\section{Results}

1. Characteristics of specific ${ }^{3} \mathrm{H}-\mathrm{DHA}$ binding to turkey erythrocyte membranes rat erythrocyte membranes and rat reticulocyte membranes: Table 1 shows the parameters for specific ${ }^{3} \mathrm{H}$-DHA binding to turkey erythrocyte membranes (TEM), rat reticulocyte membranes (RRM) and rat erythrocyte membranes. The maturation of rat reticulocytes to erythrocytes resulted in a marked (about 3-fold) loss of $B_{\max }$ without significant changes in $K_{d}$ value, showing agreement with previous papers $(13,18)$. In each membrane preparation. Scatchard plots (19) were linear and Hill coefficients (20) were nearly 1.0, indicating that ${ }^{3} \mathrm{H}-\mathrm{DHA}$ bound to these membranes with a single population of binding sites.

${ }^{3} \mathrm{H}-\mathrm{DHA}$ binding to RRM was rapid and saturable, reaching equilibrium by 10 to 20 min and remaining constant until $1 \mathrm{hr}$. By the addition of a large excess of propranolol $\left(10^{-5}\right.$ $M)$, the specific binding was rapidly dissociated with a half-life of $10.2 \mathrm{~min}$. By the method of Bylund and Snyder (21), the observed initial rate constant $\left(k_{\text {obs }}\right)$, the association rate constant $\left(k_{1}\right)$ and the rate constant for dissociation of $3 \mathrm{H}$-DHA binding $\left(k_{-1}\right)$ to RRM were calculated to 0.173 $\mathrm{min}^{-1}, 0.482 \mathrm{nM}^{-1} \cdot \mathrm{min}^{-1}$ and $0.068 \mathrm{~min}^{-1}$. respectively. Therefore, the equilibrium dissociation constant $\left(k_{-1} / k_{1}\right)$ for ${ }^{3} \mathrm{H}-\mathrm{DHA}$ binding to RRM was estimated to be 0.141 $n M$, which practically agreed with the $K_{a}$ value (0.103, Table 1) from Scatchard analysis.

Figure 1 shows Hofstee plots (7) for the inhibition of $3 \mathrm{H}-\mathrm{DHA}$ binding by the $\beta_{2}$ selective agonist procaterol and the $\beta_{1}$ -

Table 1. Equilibrium binding parameters for ${ }^{3} \mathrm{H}-\mathrm{DHA}$ to the rat erythrocyte and reticulocyte membranes and the turkey erythrocyte membranes

\begin{tabular}{llcl}
\hline & & Rat & Turkey \\
& Erythrocytes & Reticulocytes &.- \\
& & & Erythrocytes \\
Kal (nM) & $0.127 \pm 0.016$ & $0.103 \pm 0.008$ & - \\
B 1 ax (pmol/mg prot.) & $0.47 \pm 0.02$ & $1.29 \pm 0.04^{*}$ & $0.778 \pm 0.020$ \\
R (Scatchard plot) & $0.973 \pm 0.022$ & $0.991 \pm 0.005$ & $0.31 \pm 0.02$ \\
Hill coefficient & $1.003 \pm 0.077$ & $1.043 \pm 0.058$ & $1.087 \pm 0.004$ \\
R (Hill plot) & $0.983 \pm 0.005$ & $0.976 \pm 0.019$ & $0.990 \pm 0.002$ \\
\hline
\end{tabular}

Each value represents the mean and S.E. of 4 experiments, each performed in duplicate determinations. " $R$ " represents the correlative coefficient for Scatchard or Hill plots. " $P<0.01$, compared with rat erythrocyte membranes. 

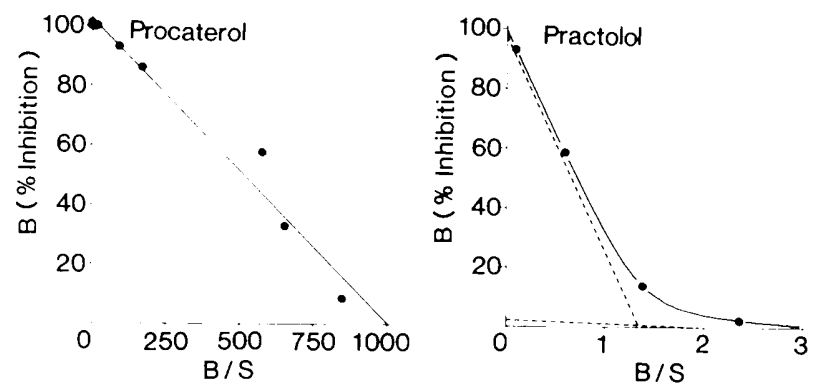

Fig. 1. Hofstee plots for the inhibition of ${ }^{3} \mathrm{H}-\mathrm{DHA}$ binding by the $\beta_{2}$-selective agonist procaterol and $\beta_{1}$-selective antagonist practolol in rat reticulocyte membranes. Each point represents the mean of 4 experiments, each performed in triplicate determinations. ${ }^{3} \mathrm{H}$-DHA binding was determined in the presence of $0.1 \mathrm{mM} \mathrm{GTP.} B$ is a $\%$ inhibition of specific ${ }^{3} \mathrm{H}-\mathrm{DHA}$ binding and $\mathrm{S}$ is the concentration of competing drug $(n M)$.

selective antagonist practolol in RRM. Computer analysis has shown that the population of $\beta_{2}$-receptors in RRM was calculated to be $99.5 \pm 0.5 \%$ (mean \pm S.E., $\mathrm{N}=4$, procaterol) and $96.1 \pm 2.2 \%$ (practolol), indicating nearly homogeneous $\beta_{2}$-receptors.

2. Effect of $\beta$-adrenergic drugs on ${ }^{3} \mathrm{H}$-DHA binding to the turkey erythrocyte membranes $\left(\boldsymbol{\beta}_{1}\right)$ : Figure 2(A) and Table 2 show the displacement curves, inhibition constants ( $K_{i}$ values) and Hill coefficients of $\beta$-adrenergic drugs for ${ }^{3} \mathrm{H}-\mathrm{DHA}$ binding to TEM. For typical catecholamines, the potency of the inhibition of ${ }^{3} \mathrm{H}-\mathrm{DHA}$ binding was in the order of isoproterenol (Iso, $26.5 \mathrm{nM}$ ) > norepinephrine (Nor, $360 \mathrm{nM}$ ) > epinephrine (Epi, $860 \mathrm{nM}$ ). This rank order was considered to reflect essentially the pharmacological characteristics of $\beta_{1}$-adrenoceptor subtype (22). The potency of the binding inhibition of other drugs in TEM was in the order of prenalterol $>$ dobutamine $\geq$ denopamine $>$ procaterol \$dopamine. The $K_{i}$ value for denopamine (1540 nM) was compatible with that of dobutamine (1380 nM) and larger than that of prenalterol (560 nM). The affinity of dopamine was extremely low, and its $K_{1}$ value was about $1 / 1900$ that of Iso.

3. Effects of $\beta$-adrenergic drugs on ${ }^{3} \mathrm{H}$ DHA binding to the rat reticulocyte membranes $\left(\boldsymbol{\beta}_{2}\right)$ : Displacement curves and $K_{i}$ values for $\boldsymbol{\beta}$-adrenergic drugs in RRM are shown in Fig. 3(A) and Table 3. The potency of the inhibition of the ${ }^{3} \mathrm{H}$-DHA binding was in the order of Iso $(7.3 \mathrm{nM})>$ Epi $(58 \mathrm{nM})>$
Nor (1090 nM), indicating that RRM has a characteristic of the $\beta_{2}$-subtype (22). In other drugs, the potency of the ${ }^{3} \mathrm{H}-\mathrm{DHA}$ binding inhibition in RRM was in the order of procaterol > prenalterol > dobutamine > denopamine $(2300 \mathrm{nM}) \gg$ dopamine. These results show that the affinity of denopamine for the $\beta_{2}$-receptor was comparably low. Practolol, a $\beta_{1}$-antagonist, showed a very low affinity among the drugs tested.

4. Effects of GTP on the inhibition of ${ }^{3} \mathrm{H}$ DHA binding to the turkey erythrocyte membranes and rat reticulocyte membranes: When $0.1 \mathrm{mM}$ GTP was added to the incubation mixture, as shown in Tables 2 and 3 and Figs. 2(B) and $3(B), K_{i}$ values for three typical catecholamines, Iso, Epi and Nor. in TEM and RRM increased by $300-500 \%$ and $200-460 \%$, respectively. Thus, it was demonstrated that the affinities of these drugs for both $\beta_{1}$ - and $\beta_{2}$-receptors decreased by the addition of GTP. Especially. $\mathrm{K}_{\mathrm{i}}$ values for Iso increased by $500 \%$ in TEM and about $460 \%$ in RRM. Denopamine showed less increase in $K_{i}$ value in TEM (70\%) than that for full agonists. In RRM, no significant changes in the inhibition curve for denopamine were observed like prenalterol, a $\beta_{1}$-partial agonist, and practolol, a $\beta_{1}$-antagonist. Whereas Hill coefficients of the competition curves for full agonists increased by the addition of GTP, those for denopamine and prenalterol hardly changed and the value was approximately 1.0 in RRM. GTP increased $K_{i}$ values for dobutamine and 

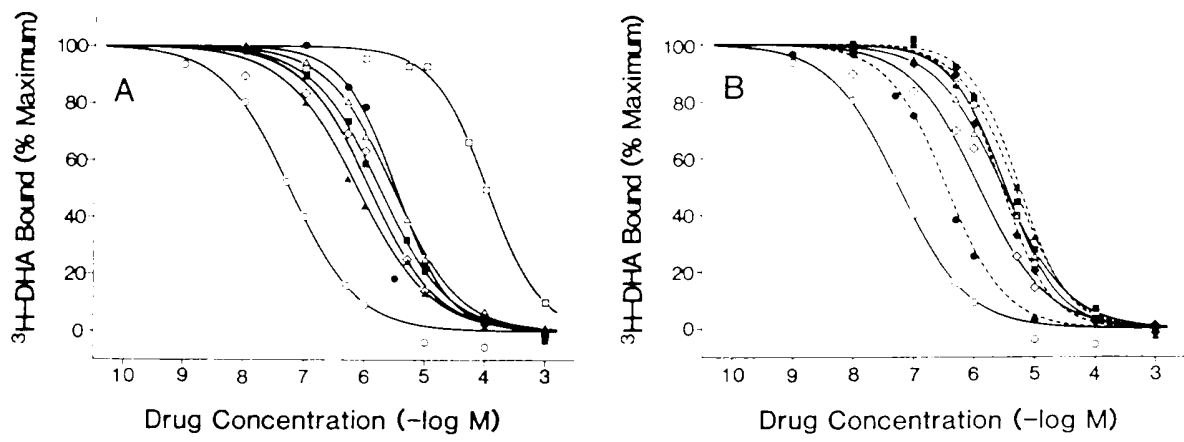

Fig. 2. Inhibition of specific ${ }^{3} \mathrm{H}$-DHA binding by $\beta$-agonists to turkey erythrocyte membranes $(A)$ and the effect of guanine nucleotide $(0.1 \mathrm{mM}, \mathrm{GTP})(B)$. Displacement curves were obtained using various concentrations of $\beta$-agonists and $0.78 \mathrm{nM}{ }^{3} \mathrm{H}$-DHA. Each point represents the mean of 4-6 experiments. and each was performed in duplicate. A: $\bigcirc$, isoproterenol: $\boldsymbol{\square}$, epinephrine; $\boldsymbol{A}$. norepinephrine; denopamine: $\triangle$, dobutamine: $\square$, dopamine; $\diamond$, prenalterol: $B: \bigcirc$, isoproterenol: $\triangle \mathbf{A}$, dobutamine; $\square$. denopamine: $\diamond \diamond$, prenalterol. Open and closed symbols represent the GTP absent and GTP present groups, respectively.

Table 2. Comparison of $K_{i}$ values and Hill coefficients of $\beta$-adrenergic drugs determined by the inhibition of ${ }^{3} \mathrm{H}$-DHA binding to turkey erythrocyte membranes in the presence and absence of guanine nucleotide (GTP. $0.1 \mathrm{mM}$ )

\begin{tabular}{|c|c|c|c|c|c|}
\hline \multirow{2}{*}{ Drugs } & \multirow{2}{*}{$N$} & \multicolumn{2}{|c|}{ GTP absent } & \multicolumn{2}{|c|}{ GTP present } \\
\hline & & $K_{i}(n M)$ & Hill & $K_{i}(n M)$ & Hill \\
\hline \multicolumn{6}{|l|}{ Agonists } \\
\hline Isoproterenol & 4 & $\begin{array}{r}26.5 \\
\pm \quad 4.8\end{array}$ & $\begin{array}{r}0.767 \\
\pm 0.022\end{array}$ & $\begin{array}{l}170^{* *} \\
\pm \quad 26\end{array}$ & $\begin{array}{l}0.893^{* * *} \\
\pm 0.019\end{array}$ \\
\hline Epinephrine & 4 & $\begin{array}{r}860 \\
\pm \quad 160\end{array}$ & $\begin{array}{r}0.760 \\
\pm 0.038\end{array}$ & $\begin{array}{l}3450^{* *} \\
\pm 510\end{array}$ & $\begin{array}{c}0.874^{*} \\
\pm 0.014\end{array}$ \\
\hline Norepinephrine & 4 & $\begin{array}{r}360 \\
\pm \quad 51\end{array}$ & $\begin{array}{r}0.705 \\
\pm 0.034\end{array}$ & $\begin{array}{l}1650^{* * *} \\
\pm 150\end{array}$ & $\begin{aligned} & 0.939^{* * *} \\
\pm & 0.037\end{aligned}$ \\
\hline Denopamine & 6 & $\begin{array}{r}1540 \\
\pm \quad 200\end{array}$ & $\begin{array}{r}0.978 \\
\pm 0.100\end{array}$ & $\begin{array}{c}2610^{*} \\
\pm \quad 420\end{array}$ & $\begin{array}{r}1.078 \\
\pm 0.069\end{array}$ \\
\hline Dobutamine & 4 & $\begin{array}{r}1380 \\
\pm \quad 220\end{array}$ & $\begin{array}{r}0.791 \\
\pm 0.029\end{array}$ & $\begin{array}{l}2190^{* *} \\
\pm \quad 77\end{array}$ & $\begin{aligned} & 0.958^{* * *} \\
\pm & 0.031\end{aligned}$ \\
\hline Dopamine & 4 & $\begin{array}{l}49500 \\
\pm 2620\end{array}$ & $\begin{array}{r}0.959 \\
\pm 0.013\end{array}$ & $\begin{array}{c}115520^{* * *} \\
\pm 9370\end{array}$ & $\begin{array}{r}1.069 \\
\pm 0.043\end{array}$ \\
\hline Prenalterol & 4 & $\begin{array}{r}560 \\
\pm \quad 23\end{array}$ & $\begin{array}{r}0.770 \\
\pm 0.062\end{array}$ & $\begin{array}{l}1320^{* * *} \\
\pm 150\end{array}$ & $\begin{array}{l}1.083^{*} \\
\pm 0.082\end{array}$ \\
\hline Procaterol & 4 & $\begin{array}{r}5161 \\
\pm \quad 674\end{array}$ & $\begin{array}{r}0.888 \\
\pm 0.079\end{array}$ & $\begin{array}{r}5831 \\
\pm \quad 532\end{array}$ & $\begin{array}{r}0.967 \\
\pm 0.099\end{array}$ \\
\hline \multicolumn{6}{|l|}{ Antagonist } \\
\hline Practolol & 4 & $\begin{array}{r}4170 \\
+\quad 340\end{array}$ & $\begin{array}{r}0.946 \\
\pm 0.039\end{array}$ & $\begin{array}{r}4020 \\
\pm \quad 540\end{array}$ & $\begin{array}{r}0.999 \\
\pm 0.049\end{array}$ \\
\hline
\end{tabular}

${ }^{*} \mathrm{P}<0.05,{ }^{* *} \mathrm{P}<0.02,{ }^{* *} \mathrm{P}<0.01$, compared with the GTP absent group. Each datum represents the mean and S.E. of 4 or 6 experiments, each performed in duplicate determinations.

dopamine respectively by about 60 and $130 \%$ in TEM and by 100 and $150 \%$ in RRM.

Figure 4 shows schematic representation of the effect of GTP on the $K_{i}$ values in TEM and RRM. $K_{i}$ values for full agonists like Iso, Epi and Nor increased in both membrane 

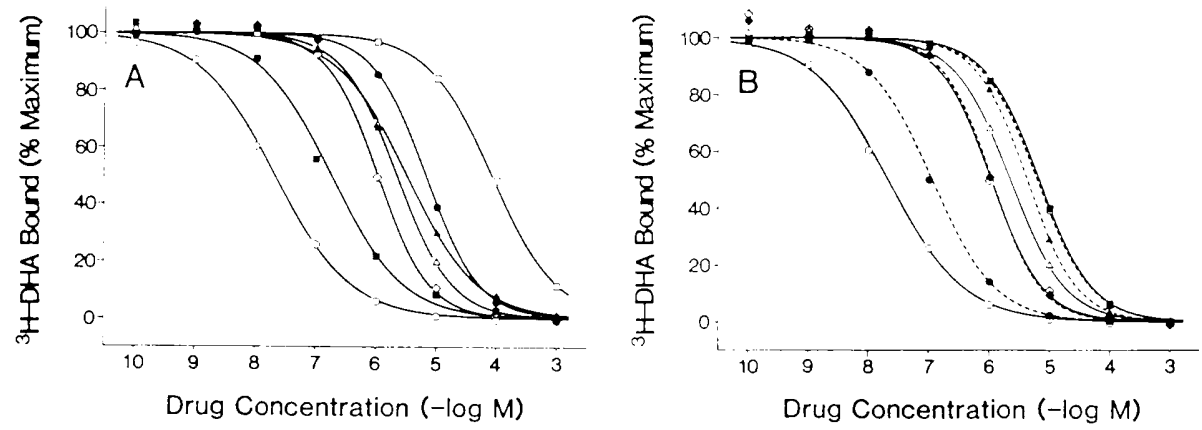

Fig. 3. Inhibition of specific ${ }^{3} \mathrm{H}$-DHA binding by $\beta$-agonists to the rat reticulocyte membranes $(\mathrm{A})$ and the effect of guanine nucleotide $(0.1 \mathrm{mM}$. GTP) (B). Displacement curves were obtained using various concentrations of $\beta$-agonists and $0.2 \mathrm{nM}{ }^{3} \mathrm{H}$-DHA. Each point represents the mean of 4-5 experiments, and each was performed in triplicate. The lines through the data represent the best fit curves from the computer modeling procedures described in "Meterials and Methods". $\mathrm{A}: \mathrm{O}$. isoproterenol; $\mathbf{\square}$, epinephrine: $\boldsymbol{\Delta}$, norepinephrine: $\boldsymbol{O}$. denopamine: $\triangle$. dobutamine: $\square$. dopamine: $\diamond$. prenalterol; $B$ : isoproterenol: $\triangle \boldsymbol{\Lambda}$, dobutamine: $\square$. denopamine: $\diamond$. prenalterol. Open and closed symbols represent the GTP absent and GTP present groups, respectively.

Table 3. Comparison of $K_{i}$ values and Hill coefficients of $\beta$-adrenergic drugs determined by the inhibition of ${ }^{3} \mathrm{H}-\mathrm{DHA}$ binding to rat reticulocyte membranes in the presence and absence of guanine nucleotide (GTP, $0.1 \mathrm{mM}$ )

\begin{tabular}{|c|c|c|c|c|c|}
\hline \multirow{2}{*}{ Drugs } & \multirow{2}{*}{ N } & \multicolumn{2}{|c|}{ GTP absent } & \multicolumn{2}{|c|}{ GTP present } \\
\hline & & $K_{i}(n M)$ & Hill & $K_{i}(n M)$ & Hill \\
\hline \multicolumn{6}{|l|}{ Agonists } \\
\hline Isoproterenol & 4 & $\begin{array}{r}7.3 \\
\pm \quad 0.5\end{array}$ & $\begin{array}{r}0.688 \\
\pm 0.019\end{array}$ & $\begin{array}{c}41^{* * *} \\
\pm \quad 2\end{array}$ & $\begin{array}{l}0.824^{* * *} \\
\pm 0.016\end{array}$ \\
\hline Epinephrine & 4 & $\begin{array}{r}58 \\
\pm \quad 7\end{array}$ & $\begin{array}{r}0.727 \\
\pm 0.057\end{array}$ & $\begin{array}{l}210^{* *} \\
\pm \quad 30\end{array}$ & $\begin{array}{r}0.810 \\
\pm 0.048\end{array}$ \\
\hline Norepinephrine & 4 & $\begin{array}{r}1090 \\
\pm \quad 150\end{array}$ & $\begin{array}{r}0.735 \\
\pm 0.028\end{array}$ & $\begin{array}{l}3390^{* * *} \\
\pm 300\end{array}$ & $\begin{array}{l}0.866^{*} \\
\pm 0.045\end{array}$ \\
\hline Denopamine & 5 & $\begin{array}{r}2300 \\
\pm \quad 310\end{array}$ & $\begin{array}{r}0.966 \\
\pm 0.021\end{array}$ & $\begin{array}{r}2120 \\
\pm \quad 130\end{array}$ & $\begin{array}{r}0.950 \\
\pm 0.022\end{array}$ \\
\hline Dobutamine & 4 & $\begin{array}{r}750 \\
+\quad 52\end{array}$ & $\begin{array}{r}0.939 \\
\pm 0.005\end{array}$ & $\begin{array}{c}1420^{* * *} \\
\pm \quad 33\end{array}$ & $\begin{array}{r}1.027 \\
\pm 0.039\end{array}$ \\
\hline Dopamine & 4 & $\begin{array}{r}26780 \\
\pm 1030\end{array}$ & $\begin{array}{r}0.793 \\
\pm 0.027\end{array}$ & $\begin{array}{l}64980^{* * * *} \\
\pm 4760\end{array}$ & $\begin{array}{l}0.946^{* * *} \\
\pm 0.009\end{array}$ \\
\hline Prenalterol & 4 & $\begin{array}{r}360 \\
\pm \quad 25\end{array}$ & $\begin{array}{r}1.013 \\
\pm 0.043\end{array}$ & $\begin{array}{r}370 \\
\pm \quad 25\end{array}$ & $\begin{array}{r}1.071 \\
\pm 0.057\end{array}$ \\
\hline Procaterol & 4 & $\begin{array}{r}17.3 \\
\pm \quad 2.9\end{array}$ & $\begin{array}{r}0.990 \\
\pm 0.058\end{array}$ & $\begin{array}{c}35.5^{*} \\
\pm \quad 5.0\end{array}$ & $\begin{array}{r}1.057 \\
\pm 0.025\end{array}$ \\
\hline \multicolumn{6}{|l|}{ Antagonist } \\
\hline Practolol & 4 & $\begin{array}{l}21920 \\
\pm 1450\end{array}$ & $\begin{array}{r}0.905 \\
\pm 0.012\end{array}$ & $\begin{array}{l}23590 \\
\pm 2400\end{array}$ & $\begin{array}{r}0.954 \\
\pm 0.041\end{array}$ \\
\hline
\end{tabular}

${ }^{*} P<0.05,{ }^{* *} P<0.02,{ }^{* * *} P<0.01$, compared with the GTP absent group. Each datum represents the mean and S.E. of 4 or 5 experiments, each performed in triplicate determinations.

preparations and their arrows directed to the upper-right. The arrows of denopamine directed only rightward, and the length of the $X$ component was shorter than full agonists. 


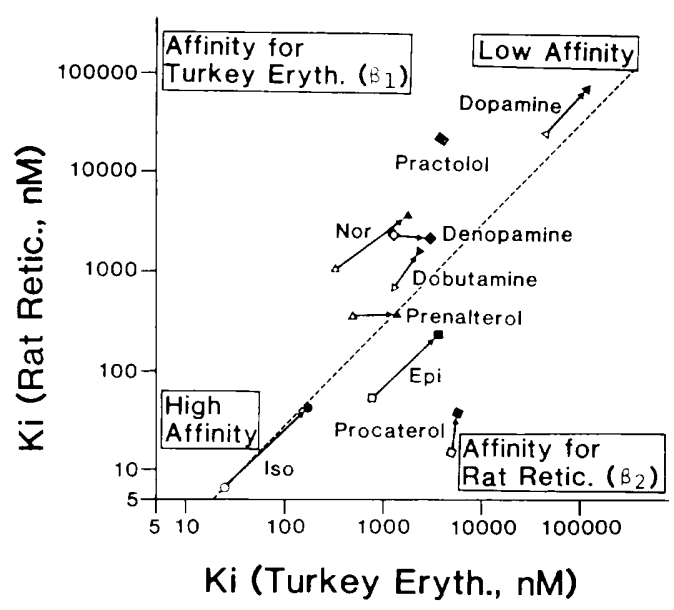

Fig. 4. Schematic representation of the effect of guanine nucleotide $\left(0.1 \mathrm{mM}\right.$. GTP) on the $K_{i}$ values for the inhibition of specific ${ }^{3} \mathrm{H}$-DHA binding to turkey erythrocyte membranes and rat reticulocyte membranes by $\beta$-adrenergic drugs. The $X$-axis represents the $K_{i}$ values of $\beta$-adrenergic drugs for TEM and $Y$-axis, those for RRM. Closed and open symbols in the figure show the affinity of the drugs with and without GTP $(0.1 \mathrm{mM})$, respectively. Therefore, the length of $X$ and $Y$ components of the arrows respectively show the degrees of the increase in $K_{i}$ values in $\operatorname{TEM}\left(\beta_{1}\right)$ and $\operatorname{RRM}\left(\beta_{2}\right)$.

On the other hand, the arrow of the $\beta_{2-}$ selective agonist procaterol directed upward. In the case of practolol, a $\beta_{1}$-antagonist, $K_{i}$ values in both TEM and RRM were hardly influenced by GTP.

\section{Discussion}

The turkey erythrocyte membranes (TEM) and the rat reticulocyte membranes (RRM) possess $\beta$-agonist sensitive adenylate cyclase systems (10-12). TEM is known to be a homogeneous $\beta_{1}$-adrenoreceptor model (10). However, RRM is only suggested to have a homogeneous population of $\beta_{2}$-receptors, though the rat erythrocyte membranes possess homogenous $\beta_{2}$-receptors $(11-13)$. In our present experiment using RRM, Hofstee plots for both $\beta_{1}$ - and $\beta_{2}$-selective drugs were aimost linear (Fig. 1), and the computer analysis has demonstrated that RRM possesses a nearly homogeneous population of $\beta_{2}$-receptor subtypes. When $K_{i}$ values for the drugs tested in the present experiment in
$\operatorname{TEM}\left(\beta_{1}\right)$ and $\operatorname{RRM}\left(\beta_{2}\right)$ were compared with those in the rat heart $\left(\beta_{1}\right)$ and lung $\left(\beta_{2}\right)$ membranes (4), respectively, a good correlation was observed in the same receptor subtypes (TEM and rat heart: $r=0.998, R R M$ and rat lung: $r=0.991$ ).

When the agonist $(H)$ interacts with the receptor (R), both the low affinity $(H-R)$ and high affinity complexes $(H-R-N)$ are formed. Then, the $\mathrm{N}$ protein of the $\mathrm{H}-\mathrm{R}-\mathrm{N}$ complex is subjected to a conformational change and dissociates with GTP from the complex in the presence of GTP. Thus, the ternary high affinity complex $(\mathrm{H}-\mathrm{R}-\mathrm{N})$ is reverted to the low affinity form ( $H-R)$. Therefore, the interaction of two affinity states is converted into that of a single population of receptor sites and the Hill coefficient approaches 1.0 by the addition of $\operatorname{GTP}(9,16)$. In the present experiment, $K_{i}$ values for Iso, Epi and Nor increased by about $300-500 \%$ in TEM and $200-460 \%$ in RRM, and Hill coefficients for these agonists also increased by the addition of GTP (Figs. 2 and 3 , Tables 2 and 3 ). These results indicated that the agonist specific high affinity complex with receptors transformed to the low affinity complex as described above. It is well characterized that the higher the ability to form the high affinity complex with receptors, the stronger the intrinsic activity of agonists $(8,9)$.

We compared the difference between $K_{i}$ values with and without GTP to estimate the ability to form the high affinity complex. The present experiment has demonstrated that denopamine exhibits agonist binding to the $\beta_{1}$-receptor in TEM and has lower ability to form the high affinity complex than full agonists. This suggests that denopamine has lower intrinsic activity than full agonists at the $\beta_{1}$-receptor. On the contrary, both the $K_{i}$ value and Hill coefficient of denopamine for the inhibition curve in RRM were hardly changed by the addition of GTP, and its affinity $\left(K_{i}\right)$ to $\beta_{2}$-receptor was comparably low among the drugs tested. This infers that denopamine possesses extremely low or almost no agonist property at $\beta_{2}$-receptors. In reference to this, Inamasu et al. (23) demonstrated that denopamine elevated the cellular cyclic AMP levels of the adipocytes 
$\left(\beta_{1}\right)$, but did not affect those of the diaphragm $\left(\beta_{2}\right)$ and reticulocytes $\left(\beta_{2}\right)$ in rats. Furthermore, Nagao et al. (2) reported that denopamine produced a very weak vasodilating effect, which was partly reduced by propranolol, showing a very weak agonistic action at $\beta_{2}$-receptors. Our present experiment essentially corresponded with the above pharmacological experiments.

As for selectivity for $\beta_{1}$ - and $\beta_{2}$-receptor subtypes, direct comparison of the $K_{1}$ values for the two membrane preparations was not considered to be meaningful, because the two membrane sources are from two different animal species. Therefore, we tentatively drew a line in Fig. 4 dividing $\beta_{1}$ - and $\beta_{2}$ selective drugs through the point for the nonselective $\beta$-agonist Iso without GTP in parallel with the diagonal line of identity.

Since dobutamine exhibited affinity for both $\beta_{1}$ - and $\beta_{2}$-receptors and $K_{i}$ values for both membranes were influenced by GTP. the drug was suggested to have agonist properties to both receptors. In dopamine, the $\mathrm{K}_{\mathrm{i}}$ value and Hill coefficient were significantly influenced by the addition of GTP like dobutamine, but $\beta$-adrenergic action of this drug may be caused only at high concentration, since the affinities for TEM and RRM were extremely low. Prenalterol exhibited comparably high affinities and a similar binding characteristic to denopamine in both membrane preparations, although the $\beta_{1}$ selectivity was lower than denopamine as shown in Fig. 4. In the preveous paper (4), prenalterol hardly exhibited the agonist affinity to the rat heart membranes $\left(\beta_{1}\right)$. Denopamine, on the other hand, showed a significant rightward shift of the competition curve by the addition of GTP in the same membrane preparation (4). This may be related to the tissue selectivity of prenalterol (24).

On the basis of the present findings, denopamine exhibited agonist affinity for TEM containing homogeneous $\beta_{1}$-receptors, though the affinity of the drug for $\operatorname{RRM}\left(\beta_{2}\right)$ was comparably low and was hardly affected by a sufficient amount of GTP. This suggests that the drug possesses an agonist property at the $\beta_{1}$-receptor and extremely low or almost no agonist property at the $\beta_{2}$-receptor and that the intrinsic activity at the $\beta_{1}$-receptor is lower than full agonists. In this sense, denopamine is considered to have a characteristic of highly selective $\beta_{1}$-adrenoceptor partial agonist in the binding experiments.

Acknowledgement: We thank Mr. M. Inamasu for valuable discussions, and we also thank Miss $Y$. Yamaguchi for technical assistance.

\section{References}

1 Nagao, T., Ikeo, T., Sato, M., Nakajima, H. and Kiyomoto, A.: Positive inotropic effect of $(-)-\alpha-$ (3,4-dimethoxyphenethylaminomethyl) -4-hydroxybenzyl alcohol (TA-064) in the dog. Eighth International Congress of Pharmacology. Tokyo, Abstract, p. 499 (1981)

2 Nagao, T., Ikeo, T., Murata, S., Sato, M. and Nakajima, H.: Cardiovascular effects of a new positive inotropic agent, $(-)-(R)-1-(p-h y-$ droxyphenyl)-2-[(3,4-dimethoxyphenethyl)amino] ethanol (TA-064) in the anesthetized dog and isolated guinea pig heart. Japan. J. Pharmacol. 35, 415-423 (1984)

3 Kino, M., Hirota, Y., Yamamoto, S., Sawada, K., Moriguchi, M., Kotaka, M., Kubo, S. and Kawamura, K.: Cardiovascular effects of a newly synthesized cardiotonic agent (TA-064) on normal and diseased hearts. Am. J. Cardiol. 51, 802-810 (1983)

4 Naito, K., Nagao, T., Otsuka, M., Harigaya, S. and Nakajima, $\mathrm{H}$.: Studies on the affinity and selectivity of denopamine (TA-064), a new cardiotonic agent, for $\beta$-adrenergic receptors. Japan. J. Pharmacol. 38, 235-241 (1985)

5 U'Prichard, D.C., Bylund, D.B. and Snyder, S.H.: $( \pm)-\left[{ }^{3} \mathrm{H}\right]$ Epinephrine and $(-)-\left[{ }^{3} \mathrm{H}\right]$ dihydroalprenolol binding to $\beta_{1}$ - and $\beta_{2}$-noradrenergic receptors in brain, heart, and lung membranes. J. Biol. Chem. 253, 5090-5102 (1978)

6 Williams, L.T. and Lefkowitz, R.J.: Receptor Binding Studies in Adrenergic Pharmacology. Raven Press, New York (1978)

7 Minneman, K.P., Hegstrand, L.R. and Molinoff, P.B.: Simultaneous determination of beta- 1 and beta-2-adrenergic receptors in tissues containing both receptor subtypes. Mol. Pharmacol. 16, 34 46 (1979)

8 Kent, R.S., De Lean, A. and Lefkowitz, R.J.: A quantitative analysis of beta-adrenergic receptor interactions: Resolution of high and low affinity states of the receptor by computer modeling of ligand binding data. Mol. Pharmacol. 17, 14-23 (1979)

9 Stiles, G.L., Caron, M.G. and Lefkowitz, R.J.: $\beta$-Adrenergic receptors: Biochemical mecha- 
nisms of physiological regulation. Physiol. Rev. 64, 661-743 (1984)

10 De Lean, A., Hancock, A.A. and Lefkowitz, R.J.: Validation and statistical analysis of a computer modeling method for quantitative analysis of radioligand binding data for mixtures of pharmacological receptor subtypes. Mol. Pharmacol. 21, 5-16 (1981)

11 Dickinson, K. and Nahorski, S.R.: Homogeneity of $\beta$-adrenoceptors on rat erythrocytes. Br. J. Pharmacol. 67, 479-480 (1979)

12 Heidenreich, K.A., Weiland, G.A. and Molinoff, P.B.: Characterization of radiolabeled agonist binding to $\beta$-adrenergic receptors in mammalian tissues. J. Cyclic Nuclectide Res. 6, 217-230 (1980)

13 Kaiser, G., Wiemer, G., Kremer, G., Dietz, J. and Palm, D.: Identification and quantification of $\beta$ adrenoceptor sites in red blood cells from rats. Naunyn Schmiedebergs Arch. Pharmacol. 305, 41-50 (1978)

14 Charness, M.E., Bylund, D.B., Beckman, B.S., Hollenberg, M.D. and Snyder, S.H.: Independent variation of $\beta$-adrenergic receptor binding and catecholamine-stimulated adenylate cyclase activity in rat erythrocytes. Life Sci. 19, 243-250 (1976)

15 Lowry, O.H., Rosebrough, N.J., Farr, A.L. and Randall, R.J.: Protein measurement with the Folin phenol reagent. J. Biol. Chem. 193, 265275 (1951)

16 De Lean, A., Munson, P.J. and Rodbard, D.: Simultaneous analysis of families of sigmoidal curves: application to bioassay, radioligand assay and physiological dose response curves. Am. J. Physiol. 235, E97-E102 (1978)

17 Cheng, Y. and Prusoff, W.H.: Relationship between the inhibition constant $\left(K_{i}\right)$ and the concentration of inhibitor which causes 50 percent inhibition (IC 50) of an enzymatic reaction. Biochem. Pharmacol. 22, 3099-3108 (1973)

18 Limbird, L.E., Gill, D.M., Stadel, J.M., Hickey, A.R. and Lefkowitz, R.J.: Loss of $\beta$-adrenergic receptor-guanine nucleotide regulatory protein. Interactions accompanies decline in catecholamine responsiveness of adenylate cyclase in maturing rat erythrocytes. J. Biol. Chem. 255, 1854-1861 (1980)

19 Scatchard, G.: The attractions of proteins for small molecules and ions. Ann. N.Y. Acad. Sci. 51, 660-672 (1949)

20 Hill, A.V.: The mode of action of nicotine and curare, determined by the form of the concentration curve and the method of temperature coefficients. J. Physiol. (Lond.) 39, 361-373 (1909)

21 Bylund, D.B. and Snyder, S.H.: Beta adrenergic receptor binding in membrane preparations from mammalian brain. Mol. Pharmacol. 12, 568-580 (1976)

22 Lands, A.M., Arnold, A., McAuliff, J.P., Luduena, F.P. and Brown, T.G.: Differentiation of receptor systems activated by sympathomimetic amines. Nature 214, 597-598 (1967)

23 Inamasu, M., Totsuka, T., Morita, T. and Takeyama, S.: Adrenergic $\beta_{1}$-selectivity of a new cardiotonic drug. TA-064, in its metabolic effects in rats. Japan. J. Pharmacol. 36, Supp. 103P (1984)

24 Kenakin, T.P. and Beek, D.: Is prenalterol (H133/ 80) really a selective beta-1 adrenoceptor agonist? Tissue selectivity resulting from differences in stimulus-response relationships. J. Pharmacol. Exp. Ther. 213, 406-413 (1980) 